\title{
The Combined Effect of Retinoic Acid and LSD1 siRNA Inhibition on Cell Death in the Human Neuroblastoma Cell Line SH-SY5Y
}

\author{
Guofeng Xua Yongtao Xiao ${ }^{\mathrm{b}}$ Jimeng Huc Lili Xing ${ }^{c}$ Ou Zhao ${ }^{c}$ Yeming $\mathrm{Wu}^{\mathrm{a}}$ \\ aDepartment of Pediatric Surgery, Xinhua hospital, Shanghai Jiaotong University \\ School of Medicine, Shanghai, P.R. China; 'bShanghai Institute for Pediatric Research, Shanhai, P.R. China; \\ 'Xinhua Hospital, Shanghai Jiaotong University School of Medicine, Shanghai, P.R. China
}

\section{Key Words}

Neuroblastoma $•$ Retinoic acid $•$ Lysine-specific demethylase $1 \cdot$ Apoptosis $•$ SH-SY5Y cell line

\begin{abstract}
Aims: Retinoic acid (RA) is used pharmacologically to treat neuroblastoma (NB), but its mechanism of action is unclear and it has limited use against refractory disease. This study investigated the expression of LSD1 (also known as KDM1A) in tumors, and assessed the efficacy of combining RA treatment with the inhibition of LSD1 expression. Methods: LSD1 protein expression levels were assessed semi-quantitatively in specimens of NB and ganglioneuroblastoma (GNB), along with the apoptosis markers, Bcl-2 and Bax. The combined effect of RA and LSD1 siRNA inhibition on cell death was then assessed in the human neuroblastoma cell line, SH-SY5Y. Results: LSD1 expression was higher in NB compared to GNB, and LSD1 overexpression directly correlated with $\mathrm{Bcl}-2$ expression and inversely correlated with Bax expression. RA treatment or LSD1 siRNA inhibition alone inhibited the growth of SHSY5Y cells, but did not cause significant apoptosis or cell death. Combined treatment led to higher rates of SH-SY5Y cell death, as reflected by an increased $\mathrm{Bax} / \mathrm{Bcl}-2$ ratio. Conclusions: The combined effect of RA and LSD1 siRNA inhibition had a synergistic effect on promoting the apoptosis of NB cells. This novel approach may improve the clinical treatment of NB.
\end{abstract}

Copyright @ 2013 S. Karger AG, Basel

\section{Introduction}

Neuroblastoma (NB) is the most predominant tumors occurring during early childhood. For example, it is the most common extracranial solid neoplasm in children, is responsible for $7 \%$ of malignancies in patients younger than 15 years, and represents $\sim 15 \%$ of deaths due to childhood cancer [1]. NB has a favorable prognosis when diagnosed prenatally or in the newborn period; however, tumors that are diagnosed after the first year are often more 
aggressive with extensive metastatic disease and an unfavorable prognosis [2]. The clinical course of NB is heterogeneous, and has been classified as low, intermediate or high risk. Low risk disease has a favorable prognosis, whereas high risk NB is difficult to treat, even with intensive chemotherapy, surgery, radiotherapy and stem cell transplantation. NB has been linked to distinct genetic variants, including $N$-myc amplification [3], 1p36 and 11q deletion [4], and 1q21.1 deletion or duplication [5]. About $20 \%$ to $50 \%$ of patients with high risk NB are progressive or refractory [6], and therapies are still very poor for refractory disease.

Retinoic acid (RA) is a natural and synthetic derivative of vitamin A [7] which is known to exert profound effects on cell proliferation, differentiation and morphogenesis, by acting through nuclear RA receptors and retinoid X receptors [8, 9]. Previous studies have reported that RA has antitumor effects on NB-derived cell lines, accompanied by a marked decrease in the expression level of $N$-myc [10]. It has also been reported that exposure to all-trans-RA can induce NB-derived cells to undergo neuronal differentiation, cell cycle arrest $[11,12]$. RA is used pharmacologically to treat NB. However, the mechanism of action of RA remains unclear and its effects against refractory disease are limited [13]. Clinical resistance to this agent is a significant problem for ongoing NB treatment [14].

Lysine-specific demethylase 1 (LSD1), also known as KDM1A, was the first histone demethylase to be identified [15]. LSD1 belongs to the flavin adenine dinucleotidedependent amine oxidase superfamily, and is known to specifically demethylate mono- or dimethylated histone H3 lysine 4 and H3 lysine 9 via a redox process [16-18]. Since LSD1 was discovered, increasing evidence has shown that its deregulation has a significant impact on human carcinogenesis, for example, LSD1 has been implicated in the etiology of various cancers including breast cancer [19], prostate cancer [20], and Ewing's sarcoma [21]. In this study we observed that LSD1 was strongly expressed in NB, and that its expression strongly correlated with the expression of Bcl-2. While RA treatment or LSD1 inhibition alone slightly affected the growth of SH-SY5Y cells, combined treatment caused significant apoptosis, which was associated with an inhibition of Bcl-2 expression and increased Bax expression.

\section{Materials and Methods}

Tissue microarrays and immunohistochemistry

Tissue microarrays (TMAs) were constructed according to a previously described method [22]. TMA blocks were cut into $5 \mu \mathrm{m}$ sections and processed for immunohistochemistry in accordance with a previously described protocol [23]. In brief, TMA sections were first dewaxed and rehydrated, endogenous peroxidase activity was then blocked using $0.3 \% \mathrm{H}_{2} \mathrm{O}_{2}$. Sections were incubated with $10 \%$ goat serum for 30 mins and incubated with the following primary antibodies overnight at $4^{\circ} \mathrm{C}$ : anti-LSD1 (1:100 dilution; Cell Signal Technology, USA) anti-Bcl-2 (1:200 dilution; Santa Cruz Biotechnology, USA) or anti-Bax (1:200 dilution; Santa Cruz Biotechnology, USA). Subsequently, sections were incubated with a secondary antibody (1:2000 dilution; Thermo Scientific, USA) or $1 \mathrm{~h}$ at room temperature. Visualization of immunostaining was achieved using the Envision System with diaminobenzidine (Dako, Glostrup, Denmark).

\section{Evaluation of immunostaining}

LSD1, Bcl-2, and Bax immunostaining were scored using a semi-quantitative method to evaluate the percentage of positive tumor cells (0-100\%). Scores were categorized in 25\% increments (i.e. 0\%, 25\%, 50\%, $100 \%$ ), as described previously [24]. Protein expression was scored by three independent pathologists, who were blinded to the clinical data. A score was accepted if at least two of the pathologists were in agreement.

\section{Cell culture}

SH-SY5Y cells were obtained from the American Type Culture Collection. The cell line was choosen because SH-SY5Y cells are aggressive and poorly differentiated. SH-SY5Y is a "N" type NB cell line with small rounded adherent clumps and short spiny neuritic processed form. Cells were cultured in 1:1 mixture of Dulbecco's modified Eagle's medium and Ham's F12 medium supplemented with $2 \mathrm{mM}$ L-glutamine and $10 \%$ heat-inactivated fetal bovine serum at $37^{\circ} \mathrm{C}$ in a humidified $5 \% \mathrm{CO}_{2}$ atmosphere. 
Cell proliferation assay

Cell proliferation was measured using a cell counting kit-8 (CCK-8, Dojindo Molecular Technologies, Japan), in accordance with the manufacturer's protocol. Briefly, the cell counting reagent was added to SH-SY5Y cells growing in 96-well plates, which were then incubated at $37^{\circ} \mathrm{C}$ for $2 \mathrm{~h}$ in a humidified $5 \%$ $\mathrm{CO}_{2}$ atmosphere. Metabolically-active cells convert the water-soluble tetrazolium salt to a yellow-colored formazan dye product. The formazan dye is soluble in tissue culture medium and the quantity of formazan product, measured by absorbance at $450 \mathrm{~nm}$, is directly proportional to the number of living cells in culture.

\section{Apoptosis and Cell cycle analysis}

To detect the changes of apoptosis, SH-SY5Y cells were were analyzed with Annexin V-EGFP/PI Apoptosis Detection Kit (R\&S Biotech, Shanghai) according to the protocol of manufature. To monitor changes in the cell cycle distribution, cells were harvested $48 \mathrm{hr}$ after treatment, washed with PBS, fixed in $70 \%$ ethanol and stained with $10 \mathrm{mg} / \mathrm{ml}$ propidium iodide.

\section{LSD1 siRNA transfection}

Cells were seeded in a six-well cell culture plate $\left(2 \times 10^{5}\right.$ cells/well $)$ in $2 \mathrm{ml}$ antibiotic-free normal growth medium supplemented with $10 \%$ FBS. The cells were incubated at $37^{\circ} \mathrm{C}$ in a $\mathrm{CO}_{2}$ incubator until the cells were $60-80 \%$ confluent. This usually took 18-24 hours. Then, SH-SY5Y cells were transiently transfected with a small interfering RNA (siRNA) targeted against $L S D 1$, or with a scrambled control siRNA (Santa Cruz Biotechnology, USA) according to the manufacturer's protocol.

\section{Protein extraction and Western blot analysis}

Western blotting was used to determine LSD1, PARP, Bcl-2 and Bax expression levels in extracts from SH-SY5Y cells grown in a 6-well plate. The cells were washed twice with cold PBS before adding radioimmunoprecipitation assay lysis buffer containing a protease inhibitor cocktail and a phosphatase inhibitor cocktail (Thermo Scientific). Extracts were centrifuged at $12,000 \mathrm{~g}$ for 15 mins at $4^{\circ} \mathrm{C}$ and the protein concentration was determined using a BCA protein assay (Thermo Scientific). Forty microgram-aliquots of extracted protein were run on SDS-polyacrylamide gels and transferred to nitrocellulose membranes. The membranes were then incubated with primary antibodies, anti-full length PARP and anti-cleaved PARP from Abcam (USA), and others as indicated above, at $4^{\circ} \mathrm{C}$ overnight; the membranes were then incubated with secondary antibody coupled to horseradish peroxidase for $2 \mathrm{~h}$. Immunoreactivity was visualized using enhanced chemiluminescence reagents (Thermo Scientific) and protein bands were quantified with a densitometer (Chemidoc MP; Bio Rad).

\section{Statistical analysis}

Statistical analysis was performed using SPSS Version 19.0 (SPSS; IBM, USA). The association between LSD1 expression and other variables was analyzed using the Spearman rank test. Other statistical analyses were carried out using the Student's t-test for unpaired data. A difference was considered significant if the $p$-value from a two-tailed test was less than 0.05 .

\section{Results}

LSD1 is expressed in neuroblastoma and correlates significantly with Bcl-2 expression

In this study, we initially analyzed expression of LSD1 using a TMA containing 48 specimens, including 32 NBs and 16 GNBs. The clinical data for each specimen, as well as the score for LSD1, Bcl-2 and Bax expression is presented in Table 1. Our data shows that LSD1 was expressed at a relatively higher level in NB compared to GNB (Fig. 1). Similarly, Bcl-2 was also overexpressed in NB, and at relatively higher levels than in GNB (Fig. 1). In contrast, the expression of Bax was much lower in NB and GNB (Fig. 1). Correlations amongst LSD1, Bcl-2 and Bax expression were analyzed by the Spearman's rank test (Table 1). The results indicated that LSD1 expression positively correlated with the expression of Bcl-2 (LSD1 vs. Bcl-2: rho $=0.537 ; p=0.001$ ), and was inversely correlated with the expression of Bax (LSD1 vs. Bax; rho $=0.434, p=0.03$ ). 


\begin{tabular}{|c|c|c|}
\hline \multirow{2}{*}{$\begin{array}{l}\text { Cellular Physiology } \\
\text { and Biochemistry }\end{array}$} & Cell Physiol Biochem 2013;31:854-862 & \\
\hline & $\begin{array}{l}\text { DOI: 10.1159/000350103 } \\
\text { Publisnea onine: June II, } 2013\end{array}$ & $\begin{array}{l}\text { O } 2013 \text { S. Karger AG, Basel } \\
\text { www.karger.com/cpb }\end{array}$ \\
\hline
\end{tabular}

\begin{tabular}{|c|c|c|c|c|c|c|c|c|}
\hline $\begin{array}{c}\text { Samples } \\
\text { NO }\end{array}$ & $\begin{array}{l}\text { Gender } \\
(\mathrm{M} / \mathrm{F})\end{array}$ & $\begin{array}{l}\text { Years } \\
\text { (Y/M) }\end{array}$ & Diagnosis & $\begin{array}{l}\text { Clinical } \\
\text { Stages }\end{array}$ & $\begin{array}{l}\text { Lymph node } \\
\text { metastasis } \\
\text { (Y/N) }\end{array}$ & LSD1 & Bcl-2 & Bax \\
\hline 1 & M & $8 \mathrm{M}$ & NB & IV & $\mathrm{N}$ & +++ & ++ & - \\
\hline 2 & $\mathrm{~F}$ & $18 \mathrm{M}$ & NB & III & $\mathrm{Y}$ & ++ & ++ & - \\
\hline 3 & $\mathrm{~F}$ & $2 \mathrm{Y}$ & NB & I-II & $\mathrm{N}$ & ++ & ++ & - \\
\hline 4 & M & $22 \mathrm{M}$ & NB & IV & $\mathrm{N}$ & ++ & ++ & - \\
\hline 5 & M & $1 Y$ & NB & IV & $\mathrm{Y}$ & +++ & +++ & - \\
\hline 6 & M & $3 Y$ & NB & IV & $\mathrm{N}$ & + & ++ & - \\
\hline 7 & M & $2 \mathrm{Y}$ & NB & IV & Y & +++ & +++ & ++ \\
\hline 8 & M & $2 \mathrm{Y}$ & NB & III-IV & $\mathrm{Y}$ & ++++ & ++++ & - \\
\hline 9 & $\mathrm{~F}$ & $14 \mathrm{M}$ & NB & IV & Y & ${ }^{++++}$ & ++ & - \\
\hline 10 & M & $11 \mathrm{M}$ & NB & III & $\mathrm{Y}$ & ++++ & ++++ & + \\
\hline 11 & M & $6 \mathrm{M}$ & NB & II & $\mathrm{Y}$ & ${ }_{++++}^{++}$ & ++++ & ++ \\
\hline 12 & $\mathrm{~F}$ & $5 Y$ & NB & IV & $\mathrm{Y}$ & ++++ & ++++ & + \\
\hline 13 & M & $8 \mathrm{M}$ & NB & I & $\mathrm{Y}$ & +++ & +++ & - \\
\hline 14 & M & $3 \mathrm{Y}$ & NB & IV & $\mathrm{N}$ & ++++ & ++ & ++ \\
\hline 15 & $\mathrm{~F}$ & $1 \mathrm{M}$ & NB & I & $\mathrm{N}$ & ++++ & ++++ & + \\
\hline 16 & M & $1 \mathrm{M}$ & NB & IV & $\mathrm{Y}$ & +++ & ++++ & + \\
\hline 17 & M & $7 \mathrm{M}$ & NB & III & $\mathrm{Y}$ & ++++ & ++++ & + \\
\hline 18 & M & $2 \mathrm{Y}$ & NB & I & $\mathrm{Y}$ & ${ }^{++++}$ & ++++ & ++ \\
\hline 19 & M & $13 \mathrm{M}$ & NB & I-II & $\mathrm{Y}$ & +++ & ++++ & ++ \\
\hline 20 & M & $2 \mathrm{Y}$ & NB & I & Y & ++++ & ++++ & ++ \\
\hline 21 & F & $3 Y$ & NB & I & $\mathrm{N}$ & +++ & ++ & + \\
\hline 22 & M & $20 \mathrm{M}$ & NB & IV & $\mathrm{N}$ & ${ }^{++++}$ & ++++ & ++++ \\
\hline 23 & M & $2 \mathrm{Y}$ & NB & III & $\mathrm{Y}$ & +++ & +++ & - \\
\hline 24 & M & $9 \mathrm{M}$ & NB & III & $Y$ & ${ }^{++++}$ & ++++ & +++ \\
\hline 25 & $\mathrm{~F}$ & $13 \mathrm{M}$ & NB & III & Y & ++++ & ++++ & ++ \\
\hline 26 & M & $2 \mathrm{Y}$ & NB & IV & $\mathrm{Y}$ & +++ & ++++ & + \\
\hline 27 & M & $7 Y$ & NB & I & $\mathrm{Y}$ & ${ }_{++++}^{++}$ & ++ & - \\
\hline 28 & $\mathrm{~F}$ & $15 Y$ & NB & I & $\mathrm{N}$ & ++ & ++ & + \\
\hline 29 & $\mathrm{~F}$ & $3 Y$ & NB & III & $\mathrm{Y}$ & ++++ & +++ & + \\
\hline 30 & M & $17 \mathrm{M}$ & NB & IV & $\mathrm{Y}$ & +++ & ++++ & + \\
\hline 31 & $\mathrm{~F}$ & $6 \mathrm{Y}$ & NB & I & Y & +++ & +++ & - \\
\hline 32 & $\mathrm{~F}$ & $8 Y$ & NB & I & Y & ${ }^{++++}$ & ++ & - \\
\hline 33 & M & $3 Y$ & GNB & IV & Y & ++ & +++ & - \\
\hline 34 & M & $3 Y$ & GNB & I & $\mathrm{Y}$ & +++ & ++ & - \\
\hline 35 & M & $4 \mathrm{Y}$ & GNB & IV & $\mathrm{Y}$ & ++++ & +++ & - \\
\hline 36 & F & $3 Y$ & GNB & IV & $\mathrm{N}$ & + & + & + \\
\hline 37 & $\mathrm{~F}$ & $3 Y$ & GNB & IV & Y & +++ & ${ }_{++++}^{++}$ & + \\
\hline 38 & M & $5 Y$ & GNB & IV & $\mathrm{Y}$ & ${ }^{++++}$ & ++++ & ++ \\
\hline 39 & M & $5 Y$ & GNB & IV & $\mathrm{Y}$ & ++++ & ++++ & + \\
\hline 40 & $\mathrm{~F}$ & $3 Y$ & GNB & III-IV & $\mathrm{N}$ & ${ }_{++++}^{++}$ & ++++ & +++ \\
\hline 41 & $\mathrm{~F}$ & $4 Y$ & GNB & I & $\mathrm{N}$ & ++++ & +++ & ++ \\
\hline 42 & M & $2 \mathrm{Y}$ & GNB & III-IV & $\mathrm{N}$ & ++++ & ++ & ++ \\
\hline 43 & M & $2 \mathrm{Y}$ & GNB & I & Y & ++++ & ++++ & ++ \\
\hline 44 & M & $3 Y$ & GNB & IV & Y & +++ & +++ & ++ \\
\hline 45 & $\mathrm{~F}$ & $2 \mathrm{Y}$ & GNB & II & $\mathrm{N}$ & +++ & +++ & + \\
\hline 46 & M & $4 \mathrm{Y}$ & GNB & II & $\mathrm{N}$ & +++ & +++ & ++ \\
\hline 47 & M & $7 \mathrm{M}$ & GNB & III & Y & +++ & ++++ & + \\
\hline 48 & $\mathrm{M}$ & $5 \mathrm{Y}$ & GNB & $\mathrm{I}$ & $\mathrm{Y}$ & ++++ & ++++ & ++ \\
\hline
\end{tabular}

Table 1. Clinicopathological features and results of LSD1, Bcl-2 and Bax immunostaining in neuroblastic tumor samples. LSD1, Bcl-2, and Bax immunostaining were scored using a semi-quantitative method to evaluate the percentage of positive tumor cells (0-100\%). Scores were categorized in $25 \%$ increments (-, negative; +, 25\% positive; ++, 50\%; +++, 75\%; ++++, 100\%). Protein expression was scored by three independent pathologists, who were blinded to the clinical data. A score was accepted if at least two of the pathologists were in agreement. (LSD1 vs. Bcl-2: rho $=0.537 ; p=0.001$ ) (LSD1 vs. Bax: rho $=0.434 ; p=0.03$ ).

Combined effect of retinoic acid and LSD1 inhibition on SH-SY5Y cells

Taking into consideration that LSD1 was overexpressed in neuroblastic tumors, we further analyzed its functional relevance in NB. SH-SY5Y cells were transiently transfected with a small interfering RNA (siRNA) directed against LSD1, or with a scrambled control siRNA. A significant knockdown of LSD1 protein expression was detected $48 \mathrm{~h}$ after transfection (Fig. 4). Upon siRNA-induced knockdown of LSD1, a decrease in cell viability 
Fig. 1. LSD1, Bcl-2 and Bax expression in NB and GNB tissue microarrays. LSD1 expression was relatively higher in NB specimens (A, B) compared to GNB (C, D). Bcl-2 was also overexpressed in NB (E, F), and present at slightly lower levels in GNB (G, H). The expression of Bax was much lower in NB (I, J) and $\mathrm{GNB}(\mathrm{K}, \mathrm{L})$.

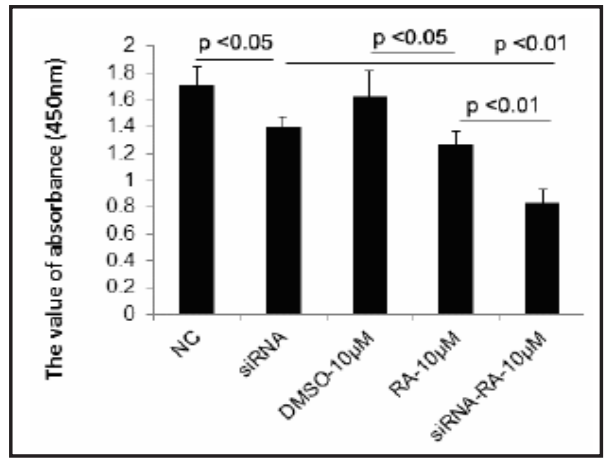

Fig. 2. The effect of RA and LSD1 inhibition alone or in combination on the growth of SH-SY5Y cells. SH-SY5Y cells were transfected with siRNA against LSD1 $(10 \mu \mathrm{M})$ or RA treatment $(10 \mu \mathrm{M})$ slightly inhibited the proliferation of SH-SY5Y cells. SH-SY5Y cells treated with combined RA and LSD1 siRNA inhibition showed a significant reduction in cell numbers after a $48 \mathrm{hr}$ incubation.

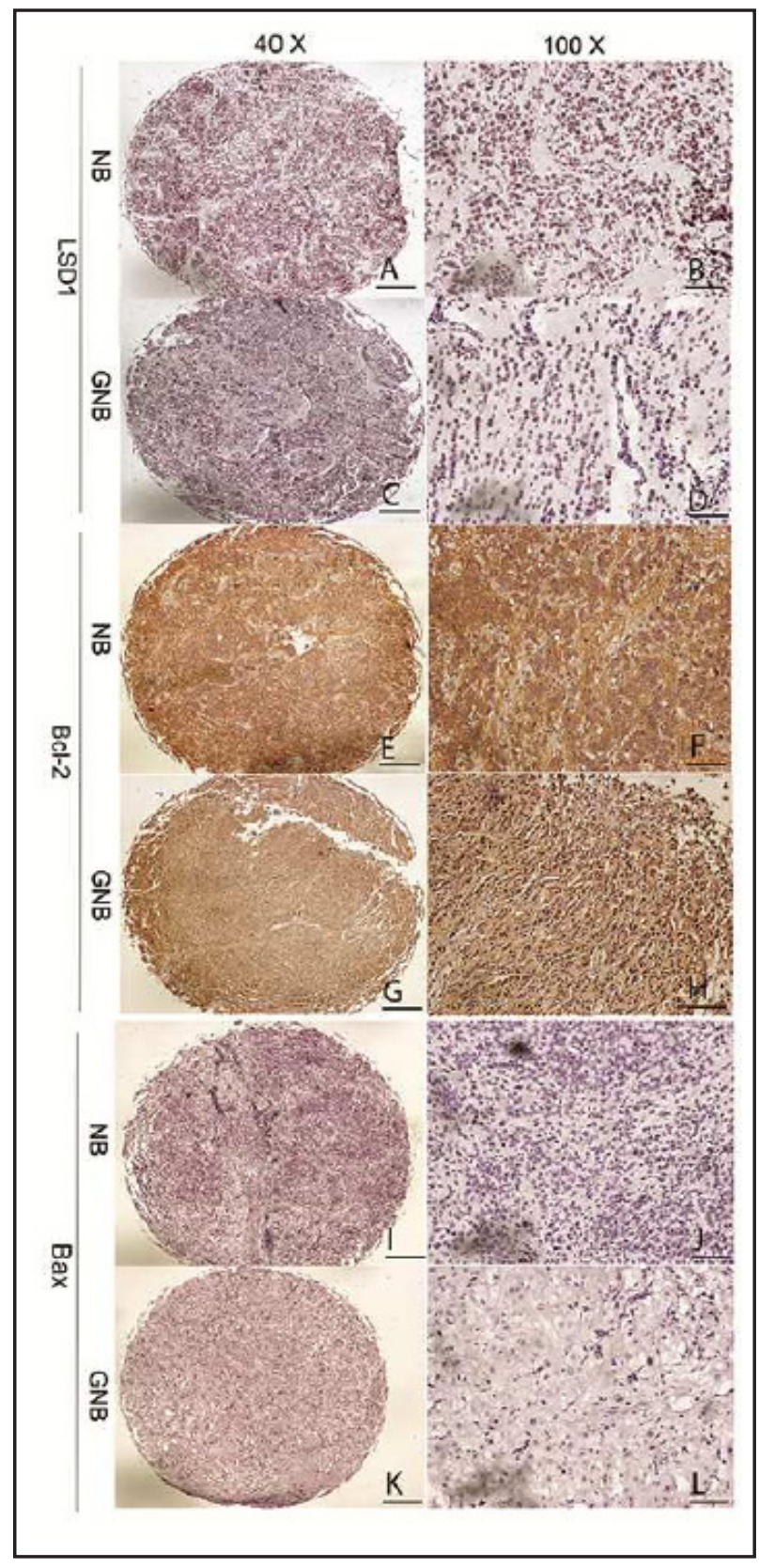

was detected using cell proliferation assays (Fig. 2). Decreased viability was accompanied by the appearance of morphologic features indicating differentiation or apoptosis, such as outgrowth of neurite-like structures and fragmentation of the nucleus. Moreover, flow cytometric analysis showed that apoptosis and subG1 fraction was increased significantly when treatment with LSD1-siRNA and RA (Fig. 3).

To examine the possible effects of RA on growth and viability of SH-SY5Y cells, the cells were cultured with $10 \mu \mathrm{M}$ RA and the numbers of viable cells were counted after 48 h. As shown in Fig. 2, $10 \mu$ M RA didn't significantly inhibited the proliferation of SH-SY5Y cells. To analyze the combined effect of LSD1 siRNA inhibition and RA on the death of SHSY5Y cells, the cells were transfected with siRNA targeting LSD1 and exposed to $10 \mu \mathrm{M} \mathrm{RA}$ for 48 h. As shown in Fig. 2, we observed an increase in cell death following the combined treatment. Furthermore, morphological changes in the form of neurite-like structures and fragmentation of the nucleus became more significant (Fig. 3). 


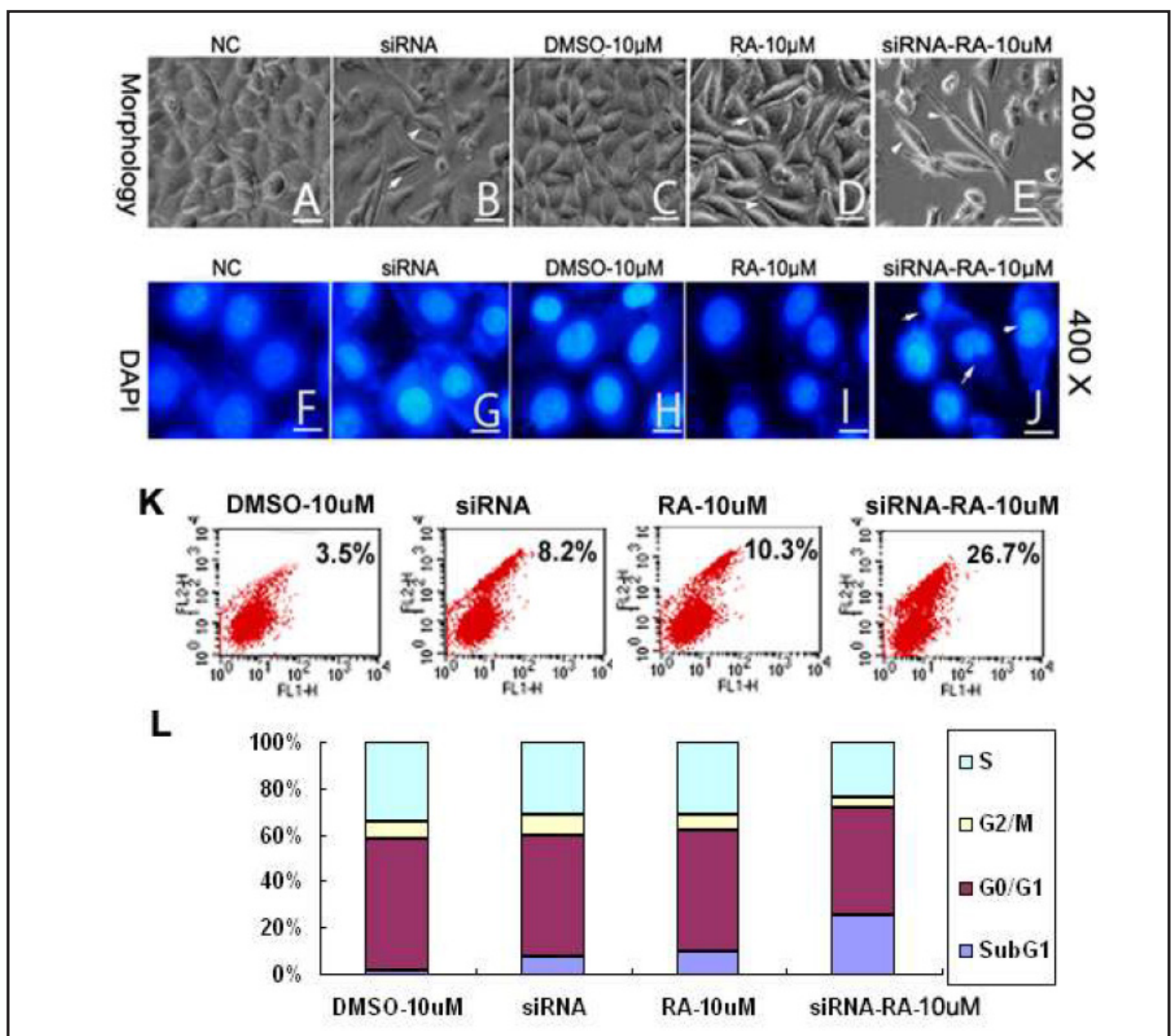

Fig. 3. Induced changes in cell morphology of SH-SY5Y cells by RA treatment and/or LSD1 inhibition using phase-contrast microscopy. (A,D,E) Arrows indicate cells with a neurite phenotype. Combined RA treatment and LSD1 siRNA inhibition resulted in a significant increase in the number and length of neurite-like structures (E), magnified by 200-fold (A-E). Nuclear fragmentation into oligonucleosomes and chromatin condensation served as an indicator of apoptosis (J). Complete nuclear body fragmentation increased significantly after combined treatment with RA and LSD1 siRNA. Arrows indicate apoptotic cells, magnification 400-fold(F-J). Flow cytometric analysis of SH-SY5Y cells after siRNA-mediated LSD1 knockdown, RA treatment or combination of them. The apoptosis and the subG1 fraction was increased significantly when treatment with LSD1-siRNA and RA, indicating increase apoptotic cell death(K,L).

To elucidate the molecular mechanisms underlying the combined effect of RA and LSD1 inhibition on apoptotic cell death in SHSY-5Y cells, we examined whether poly-ADP-ribose polymerase (PARP), one of the physiological substrates of activated caspase-3, could be proteolytically activated in response to RA and LSD1 inhibition. As shown in Fig. 4, cleavage of PARP was observed in cells with LSD1 inhibition and RA treatment alone, as well as cells treated in combination. It was apparent that the cleavage of PARP in cells with the combined treatment was higher than the single treatment groups. The Bcl-2 family includes antiapoptotic members such as Bcl-2, and pro-apoptotic members such as Bax. The ratio of Bax to $\mathrm{Bcl}-2$ has been reported to be correlated with apoptosis. Our results show that treatment of cells with $10 \mu \mathrm{M}$ RA and LSD1 siRNA inhibition induced an increase in the protein level of Bax and a decrease in the protein level of Bcl-2 (Fig. 4). Furthermore, there was an approximate 3-fold increase in the ratio of Bax/Bcl-2 expression in these cells, compared with cells treated with $10 \mu \mathrm{M}$ RA or LSD1 siRNA inhibition alone. 


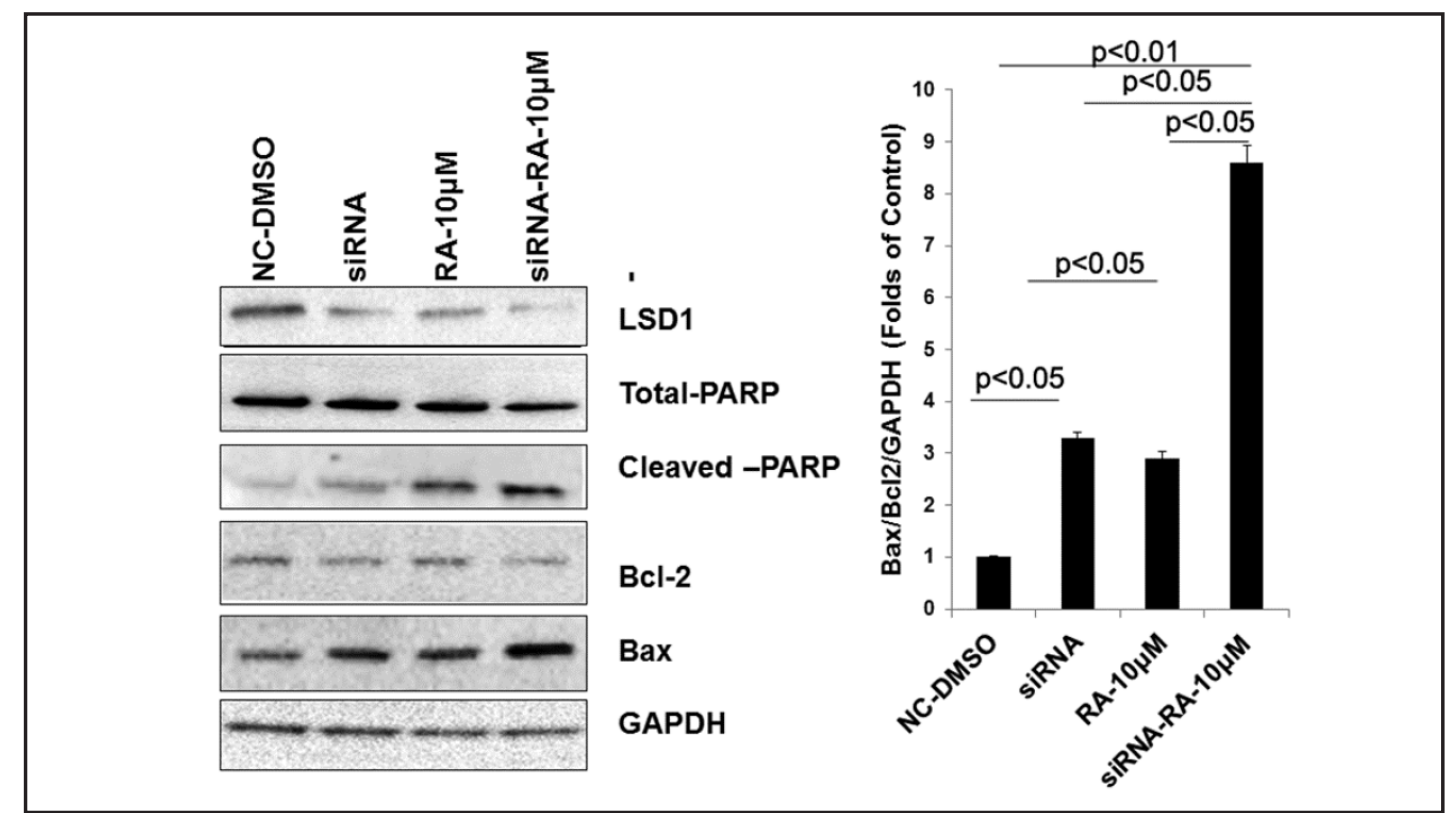

Fig. 4. The effect of LSD1 inhibition and RA treatment on LSD1, PARP cleavage, Bcl-2, and Bax expression in SH-SY5Y cells. Western blot analysis of LSD1, PARP, Bcl-2, and Bax in SH-SY5Y cells after exposure to $10 \mu \mathrm{M}$ RA and/or LSD1 siRNA inhibition for $48 \mathrm{~h}$ (left). Bcl-2 and Bax protein levels in SH-SY5Y cells were assessed using Western blotting and densitometric analysis. There was an approximate 3-fold increase in the ratio of Bax/Bcl-2 expression compared with cells treated with $10 \mu \mathrm{M}$ RA or LSD1 siRNA inhibition alone (right).

\section{Discussion}

Present therapy for NB includes surgery, chemotherapy, radiation therapy and biological approaches [25]. RA has been shown to induce neuronal differentiation and/or apoptosis, and is widely used as a chemotherapeutic agent for treating patients with NB. Despite its efficacy, the effects of RA against refractory disease are limited. Moreover, resistance to RA represents a significant drawback to its clinical application. In this study, we demonstrated that LSD1 inhibition could enhance the ability of RA to promote the death of NB cells. LSD1, the first identified histone demethylase, is overexpressed in breast cancer, small cell lung cancer, colorectal, bladder and prostate cancers and neuroblastoma [19, 26, 27].

We also found that LSD1 is strongly expressed in NB, and at much higher levels than in benign GNB. This result was consistent with reports that LSD1 expression was higher in undifferentiated neuroblastic tumors than in the differentiated tumors [27]. To further analyze the role of LSD1 in the pathogenesis of NB, we found that transient knockdown of LSD1 using siRNA increased the death of SH-SY5Y cells. Furthermore, we found that the effect of RA on the death of SH-SY5Y cells was significantly enhanced after LSD1 siRNA inhibition.

The pathogenesis of a wide variety of human diseases is frequently related to impaired control of apoptosis [28]. Indeed, we observed that Bcl-2 expression was high in neuroblastic tumors, but Bax expression was relatively low or undetectable. Moreover, expression of these proteins was correlated with LSD1 expression. This correlation suggested that the effect of RA and LSD1 inhibition on human SH-SY5Y cells may be mediated through the mitochondrial apoptotic pathway. Bcl-2 and Bax are important endogenous regulators of apoptosis and cellular activity in response to a variety of physiological and pathological insults $[29,30]$. It is known that an increase in the Bax:Bcl-2 ratio can trigger the release of mitochondrial pro-apoptotic factors such as cytochrome C, Smac and AIF into the cytosol, which mediates apoptosis [29, 31]. Interestingly, Anna et al. indicated that overexpression of Bcl-2 after RAinduced differentiation of NB cells represented a loss of the apoptotic response or resistance 


\begin{tabular}{|c|c|c|}
\hline \multirow{2}{*}{$\begin{array}{c}\text { Cellular Physiology } \\
\text { and Biochemistry }\end{array}$} & Cell Physiol Biochem 2013;31:854-862 & \\
\hline & $\begin{array}{l}\text { DOI: } 10.1159 / 000350103 \\
\text { Publisned onIIne: June } 1,2013\end{array}$ & $\begin{array}{l}\text { O } 2013 \mathrm{~S} \text {. Karger } \mathrm{AG} \text {, Basel } \\
\text { www.karger.com/cpb }\end{array}$ \\
\hline
\end{tabular}

to other chemotherapeutic drugs [32]. Treatment with RA can be led to an increase in H3K4me2 level [33], and loss of RA receptor target genes expression is associated with a reduction in H3K4me2 [34]. Here, we found that inhibition of LSD1 enhanced the effect of RA on the death of SH-SY5Y cells, through reducing the expression of Bcl-2 and increasing the levels of Bax (Fig. 4). Our results showed that there was an approximate 3-fold increase in the ratio of Bax/Bcl-2 expression in these cells, compared with cells treated with $10 \mu \mathrm{M}$ RA or LSD1 siRNA inhibition alone. In conclusion, our results suggest that a combination of LSD1 inhibition and RA treatment could be a new therapeutic option for the management of NB.

\section{Acknowledgements}

This research was supported by grant from National Natural Science Foundation of China (Grant Number 81272803).

\section{References}

1 Maris JM, Hogarty MD, Bagatell R, Cohn SL: Neuroblastoma. Lancet 2007;369:2106-2120.

2 Brodeur GM: Neuroblastoma: Biological insights into a clinical enigma. Nat Rev Cancer 2003;3:203-216.

-3 Schwab M, Alitalo K, Klempnauer KH, Varmus HE, Bishop JM, Gilbert F, Brodeur G, Goldstein M, Trent J: Amplified DNA with limited homology to myc cellular oncogene is shared by human neuroblastoma cell lines and a neuroblastoma tumour. Nature 1983;305:245-248.

4 Attiyeh EF, London WB, Mosse YP, Wang Q, Winter C, Khazi D, McGrady PW, Seeger RC, Look AT, Shimada H, Brodeur GM, Cohn SL, Matthay KK, Maris JM, Children's Oncology G: Chromosome 1p and 11q deletions and outcome in neuroblastoma. N Eng J Med 2005;353:2243-2253.

-5 Diskin SJ, Hou C, Glessner JT, Attiyeh EF, Laudenslager M, Bosse K, Cole K, Mosse YP, Wood A, Lynch JE, Pecor K, Diamond M, Winter C, Wang K, Kim C, Geiger EA, McGrady PW, Blakemore AI, London WB, Shaikh TH, Bradfield J, Grant SF, Li H, Devoto M, Rappaport ER, Hakonarson H, Maris JM: Copy number variation at 1q21.1 associated with neuroblastoma. Nature 2009;459:987-991.

6 Kushner BH, Kramer K, LaQuaglia MP, Modak S, Yataghene K, Cheung NK: Reduction from seven to five cycles of intensive induction chemotherapy in children with high-risk neuroblastoma. J Clin Oncol 2004;22:4888-4892.

7 McCaffery PJ, Adams J, Maden M, Rosa-Molinar E: Too much of a good thing: Retinoic acid as an endogenous regulator of neural differentiation and exogenous teratogen. Eur J Neurosci 2003;18:457-472.

8 Ross SA, McCaffery PJ, Drager UC, De Luca LM: Retinoids in embryonal development. Physiol Rev 2000;80:1021-1054.

-9 Lippman SM, Lotan R: Advances in the development of retinoids as chemopreventive agents. J Nutr 2000;130:479S-482S.

10 Thiele CJ, Reynolds CP, Israel MA: Decreased expression of n-myc precedes retinoic acid-induced morphological differentiation of human neuroblastoma. Nature 1985;313:404-406.

11 Melino G, Thiele CJ, Knight RA, Piacentini M: Retinoids and the control of growth/death decisions in human neuroblastoma cell lines. J Neurooncol 1997;31:65-83.

$>12$ van Noesel MM, Versteeg R: Pediatric neuroblastomas: Genetic and epigenetic 'danse macabre'. Gene 2004;325:1-15.

13 Cernaianu G, Brandmaier P, Scholz G, Ackermann OP, Alt R, Rothe K, Cross M, Witzigmann H, Trobs RB: Alltrans retinoic acid arrests neuroblastoma cells in a dormant state. Subsequent nerve growth factor/brainderived neurotrophic factor treatment adds modest benefit. J Pediatr Surg 2008;43:1284-1294.

14 Messi E, Florian MC, Caccia C, Zanisi M, Maggi R: Retinoic acid reduces human neuroblastoma cell migration and invasiveness: Effects on dcx, lis1, neurofilaments-68 and vimentin expression. BMC Cancer 2008;8:30. 


\section{Cellular Physiology Cell Physiol Biochem 2013;31:854-862

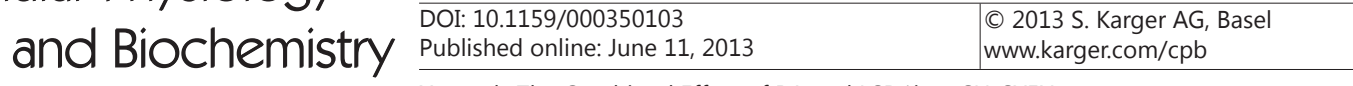 \\ Xu et al.: The Combined Effect of RA and LSD1i on SH-SY5Y}

15 Shi Y, Lan F, Matson C, Mulligan P, Whetstine JR, Cole PA, Casero RA, Shi Y: Histone demethylation mediated by the nuclear amine oxidase homolog lsd1. Cell 2004;119:941-953.

-16 Liu F, Quesada V, Crevillen P, Baurle I, Swiezewski S, Dean C: The arabidopsis rna-binding protein fca requires a lysine-specific demethylase 1 homolog to downregulate flc. Mol Cell 2007;28:398-407.

$\checkmark 17$ Mosammaparast N, Shi Y: Reversal of histone methylation: Biochemical and molecular mechanisms of histone demethylases. Annu Rev Biochem 2010;79:155-179.

18 Chen Y, Jie W, Yan W, Zhou K, Xiao Y: Lysine-specific histone demethylase 1 (lsd1): A potential molecular target for tumor therapy. Crit Rev Eukaryot Gene Expr 2012;22:53-59.

19 Lim S, Janzer A, Becker A, Zimmer A, Schule R, Buettner R, Kirfel J: Lysine-specific demethylase 1 (lsd1) is highly expressed in er-negative breast cancers and a biomarker predicting aggressive biology. Carcinogenesis 2010;31:512-520.

20 Cai C, He HH, Chen S, Coleman I, Wang H, Fang Z, Chen S, Nelson PS, Liu XS, Brown M, Balk SP: Androgen receptor gene expression in prostate cancer is directly suppressed by the androgen receptor through recruitment of lysine-specific demethylase 1. Cancer Cell 2011;20:457-471.

21 Wu CY, Hsieh CY, Huang KE, Chang C, Kang HY: Cryptotanshinone down-regulates androgen receptor signaling by modulating lysine-specific demethylase 1 function. Int J Cancer 2012;131:1423-1434.

22 Xie D, Sham JS, Zeng WF, Lin HL, Che LH, Wu HX, Wen JM, Fang Y, Hu L, Guan XY: Heterogeneous expression and association of beta-catenin, p16 and c-myc in multistage colorectal tumorigenesis and progression detected by tissue microarray. Int J Cancer 2003;107:896-902.

23 Cai MY, Zhang B, He WP, Yang GF, Rao HL, Rao ZY, Wu QL, Guan XY, Kung HF, Zeng YX, Xie D: Decreased expression of pinx1 protein is correlated with tumor development and is a new independent poor prognostic factor in ovarian carcinoma. Cancer Sci 2010;101:1543-1549.

-24 Zlobec I, Steele R, Michel RP, Compton CC, Lugli A, Jass JR: Scoring of p53, vegf, bcl-2 and apaf-1 immunohistochemistry and interobserver reliability in colorectal cancer. Mod Pathol 2006;19:1236-1242.

25 Castel V, Canete A: A comparison of current neuroblastoma chemotherapeutics. Expert Opin Pharmacother 2004;5:71-80.

26 Hayami S, Kelly JD, Cho HS, Yoshimatsu M, Unoki M, Tsunoda T, Field HI, Neal DE, Yamaue H, Ponder BA, Nakamura Y, Hamamoto R: Overexpression of lsd1 contributes to human carcinogenesis through chromatin regulation in various cancers. Int J Cancer 2011;128:574-586.

-27 Schulte JH, Lim S, Schramm A, Friedrichs N, Koster J, Versteeg R, Ora I, Pajtler K, Klein-Hitpass L, KuhfittigKulle S, Metzger E, Schule R, Eggert A, Buettner R, Kirfel J: Lysine-specific demethylase 1 is strongly expressed in poorly differentiated neuroblastoma: Implications for therapy. Cancer Res 2009;69:20652071.

-28 Papucci L, Witort E, Bevilacqua AM, Donnini M, Lulli M, Borchi E, Khabar KS, Tempestini A, Lapucci A, Schiavone N, Nicolin A, Capaccioli S: Impact of targeting the adenine- and uracil-rich element of bcl-2 mrna with oligoribonucleotides on apoptosis, cell cycle, and neuronal differentiation in shsy-5y cells. Mol Pharmacol 2008;73:498-508.

29 Shimizu S, Narita M, Tsujimoto Y: Bcl-2 family proteins regulate the release of apoptogenic cytochrome c by the mitochondrial channel vdac. Nature 1999;399:483-487.

-30 Murphy KM, Ranganathan V, Farnsworth ML, Kavallaris M, Lock RB: Bcl-2 inhibits bax translocation from cytosol to mitochondria during drug-induced apoptosis of human tumor cells. Cell Death Differ 2000;7:102-111.

31 Adams JM, Cory S: The bcl-2 protein family: Arbiters of cell survival. Science 1998;281:1322-1326.

-32 Lasorella A, Iavarone A, Israel MA: Differentiation of neuroblastoma enhances bcl-2 expression and induces alterations of apoptosis and drug resistance. Cancer Res 1995;55:4711-4716.

-33 Schenk T, Chen WC, Gollner S, Howell L, Jin L, Hebestreit K, Klein HU, Popescu AC, Burnett A, Mills K, Casero RA, Jr., Marton L, Woster P, Minden MD, Dugas M, Wang JC, Dick JE, Muller-Tidow C, Petrie K, Zelent A: Inhibition of the lsd1 (kdm1a) demethylase reactivates the all-trans-retinoic acid differentiation pathway in acute myeloid leukemia. Nature Med 2012;18:605-611.

-34 Glasow A, Barrett A, Petrie K, Gupta R, Boix-Chornet M, Zhou DC, Grimwade D, Gallagher R, von Lindern M, Waxman S, Enver T, Hildebrandt G, Zelent A: DNA methylation-independent loss of rara gene expression in acute myeloid leukemia. Blood 2008;111:2374-2377. 